\title{
Review of Some Recent Lifelong Learning Practices and Models in Russia
}

\author{
Natasha Kersha, \\ Valentina A. Kononova*b and Veronika V. Obidina ${ }^{b}$ \\ ${ }^{a}$ University College London \\ 20 Bedford Way, London, WC1H 0AL, Great Britain \\ ${ }^{b}$ Siberian Federal University \\ 79 Svobodny, Krasnoyarsk, 660041, Russia
}

Received 17.07.2015, received in revised form 27.07.2015, accepted 20.09.2015

The article discusses some modern practices and educational models of lifelong learning in Russia. A brief introduction of European schemes leads to description of modern LLL challenges and needs of society in today's Russia. The article traces links between Joseph Zaida's frame of models and recent examples of TEMPUS educational projects in Russian universities, as well as other practices for implementation of LLL initiatives.

Keywords: lifelong learning, LLL, TEMPUS LLL projects, LLL models, functionalist model, educational policies.

The article is written with the financial support of the European Commission within the Tempus IV programme (Project "Lifelong Language Learning University Centre Network for New Career Opportunities and Personal Development (UNICO)”, № 544283-TEMPUS-1-2013-1-ES-TEMPUSJPHES).

DOI: 10.17516/1997-1370-2015-8-11-2195-2200.

Research area: pedagogy, philology.

\section{Introduction}

The concept of lifelong learning (LLL) has had a long and honourable history since Plato, whose notion that "education commences in the first years of childhood and lasts to the very end of life" sounds modern, clear and attractive today. In the course of time, this idea was given repeated expression in the words of hundreds of great Western and Eastern thinkers, writers and people at large.
In the educational policies worldwide, the paradigm of lifelong learning appeared in the early 1970s, but those old wise words are closely echoed with modern LLL dimensions and trends: Learning is a treasure that will follow its owner everywhere (Chinese proverb); Live as if you were to die tomorrow. Learn as if you were to live forever (Mahatma Gandhi); Learning without thought is labour lost (Confucius); I am still learning (Michelangelo); Anyone who stops

(C) Siberian Federal University. All rights reserved

* Corresponding author E-mail address: v.kononova@mail.ru 
learning is old, whether at twenty or eighty (Henry Ford). During the last fifty years, scientific and technological innovation, economic and social changes have deeply influenced learners' needs. No longer is learning divided into university / college / school time to acquire knowledge and develop skills and a workplace to apply the knowledge and skills acquired. Instead, learning is considered as an ongoing process from our daily interactions with others and with the world around the learner.

\section{Lifelong learning as a holistic conception}

Power and presence of lifelong learning as a multifaceted paradigm has increased especially since the mid 1990s in the attention given to it by a wide range of national and international initiatives, organizations, networks and projects. In different parts of the world, lifelong learning policies differ, sometimes significantly. K. Evans classified LLL policies introduced across the globe into four types according to their stated aims (Evans, 2012: Ix):

1) a compensatory education model, whose aim is to improve basic literacy and vocational skills in an attempt to compensate for inequalities in initial schooling;

2) a continuing professional and vocational education model of workforce development, which aims to respond to and also anticipate changes in work organization as well as ameliorating unemployment;

3) a social innovation, or civil society model, which aims at overcoming social estrangement and exclusion, as well as supporting aspects of socioeconomic transition and democratization;

4) a personal development or 'leisureoriented' model which aims to enrich the personal lives of individuals and thereby health, well-being and personal fulfillment.

A range of policies and discourses on lifelong learning coexist at national as well as international level. Dominant policy discourses generated at international level are adapted to the shape of the social landscapes into which they are introduced, reflecting their underlying structural features, cultures and histories. Whether they work or not depends crucially on what people make of them.

\section{LLL angle in modern Russia}

In modern Russia, lifelong learning ideas and practices grow from old educational traditions as well as modern challenges and needs of society.

J.Zaida argues that since the 1990s, lifelong learning increasingly reflected neo-liberal ideology in Europe, focusing on economic, rather than humanistic, goals. "Lifelong learning policies ... were strongly orientated towards vocational aims. Lifelong learning in the Russian Federation appears to follow a similar trend - borrowing and adapting Western-driven paradigms of credentialism, skills and human capital. The ideas of collectivity, social justice and equity have been exchanged for key concepts from business management discourse, namely productivity, efficiency, competitiveness and quality - or the "bottom-line" of the language of profit maximization. Adult education shifted from the "learning of meanings" to the "learning of earnings" (Zaida, 2012: 441). The very notion that the future standards of living may differ from today's conditions and moreover, they will depend on the person's ability to sell his labour power, was revolutionary twenty years ago. This new entrepreneurial culture influenced educational approaches of policy-makers, teachers and students, and shaped career plans of learners at large in Russia, as elsewhere, and by now a new 
generation of learners do not miss the growing stimulating opportunities for their professional and personal development.

The Review of Lifelong Learning Policy in Thirteen European Countries of the Sixth Framework Programme declares that whilst the Russian Federation couches its policies in terms of adult education rather than the learning society, it is evident that the building of human capital is increasingly emphasised. In addition, the push to promote lifelong learning throughout Europe (including the Russian Federation) is due to the problems posed by a declining and ageing population, and the related need to enlarge the age-groups available for active participation in the labour market. Furthermore, a high proportion of younger people in Europe are from migrant groups, some of whom lack the necessary paperwork to be legally employed in the EU. Migrant workers and their children pose particular challenges for social inclusion, which lifelong learning policies are only just beginning to address (Review, 2007: 21-22).

In the Second International Handbook of Lifelong Learning, J. Zaida introduces eight educational LLL models (Zaida, 2012: 447), though a spectrum of models and practices is widening:

1) The functionalist model, focusing on "human capital", offering knowledge, skills and credentials for jobs. (stress on educational outcomes, skills and standards).

In a range of current practices, TEMPUS educational projects embracing LLL issues contribute significantly to shaping of the new educational contexts and serve here to illustrate some Zaida's models.

The functionalist model may be exemplified by the current TEMPUS VALERU project (nine Russian partners, including the Ministry of Education and Science of RF) is aimed at establishing mechanisms and human resources for the validation of non-formal/informal learning (NIL) in Russian Higher Education in order to ensure sustainable development of Russian HE. VALERU provides a methodological basis for validation, based on European approaches and well grounded in the Russian HE system and the necessities of the Russian labour market; in order to integrate learning outcomes from NIL as invaluable resource in the context of rapidly changing needs of the labour market and the development of LLL in general. It raises awareness among all stakeholders (government, citizens, HEIs, companies) for the importance to integrate NIL learning outcomes in HE in order to ensure the growing demand of highly qualified, trained human resources (http://valeru.net).

Another illustration for the functionalist model is TEMPUS project UNICO (UniversityCareer-Opportunities), the network of UNICO Language Centres among the eleven universities in the KyrgyzRepublic, the Republic of Tajikistan, and the Siberian Federal District of the Russian Federation (Krasnoyarsk, Tomsk, Novosibirsk, Barnaul, Kemerovo, Chita) as accelerators of economic growth in the remote territories with the view of the changes in society at large in terms of new opportunities in the labour market and personal development. UNICO will focus on the best modern educational technologies and programmes on the basis of acquisition of formal qualifications (certification of language competences within the requirements of the Common European Framework for Languages) for different target groups: (1) non-university adult communities, including individuals with special needs by providing them with tailored courses; (2) universities for them to be better involved into the world academic communities; (3) governmental organizations, small and large businesses; (4) sports and cultural organizations, etc. (http://tempus-unico.eu/index.php/en/ 
events/lifelong-learning-training-londonoctober-2014)

2) The critical literacy model, developing consciousness that has the power for social transformation, through dialogue and praxis.

3) The social justice model, sharing some elements with the critical literacy model and including such dimensions as social justice, human rights and equity.

The on-going project ALLMEET (Actions of Lifelong Learning addressing Multicultural Education and Tolerance in Russia) gathers 11 partners, including Kazan Federal University, Siberian Federal University (Krasnoyarsk), Northern (Arctic) Federal University (Arkhangelsk), Charitable educational organization Gold Heart (Kazan), Institute of Pedagogy and Psychology, Russian Academy of Education (Kazan), Mari State University (Ioshkar Ola), Moscow City Pedagogical University. The project is aimed at support of the Russian higher education modernization, development of higher education institutions as long-life learning centers. The focus of the project is study of migration, intercultural communication and human rights, in order to raise the level of tolerance towards people of Immigrants' background and other minorities. The project activities are focused on development of new concepts and practices in multicultural education; actions with integrative strategies of the intercultural dialogue; support of migrants' mobility; contribution to the analysis of migration policy and its development in the regions (http:// www.ec-vpl.eu/allmeet/)

4) The reflective learning model, focusing on the development of meta-level skills, whereby the individual can critically assess different theories, discourses and knowledge paradigms ('Learning how to think' model).

\section{5) The compensatory/social rehabilitation}

model, in which the educational content is intended to remedy some deficiency in education.

6) The humanistic model, in which the aim is essentially to broaden learners' horizons and enrich their minds.

A three-year TEMPUS project STREAM (Strengthening the Lifelong Learning in Environmental Sciences in Russia, 20122015) may be regarded a humanistic model. It contributed to capacity building of the partner universities with a view to their subsequent operation within the network of the 5 focal points in the Central, Southern, Siberian and Far Eastern Federal Districts of Russia. This network, through the provision of e-learning contributed to the solution of priority tasks of environmental management and engineering to meet the specific needs of key industries in the respective regions, to improve the quality of the environment. The achievement of all goals and objectives of the project contributed directly to the promotion of the use of e-learning, including distance learning technologies, which is fully consistent with the National strategy of education development in conditions of innovative development of the Russian economy, and the contemporary needs of society and every citizen. In the project, the partners designed and implemented a number of modular e-learning programmes on an ongoing basis (http://ecostream.lamp-lab.ru).

7) The pedagogy of engagement/ progressive model of lifelong learning.

Another TEMPUS project CTAE (Centre for the Third Age Education) included, among others, four Russian universities (St. Petersburg, Krasnodar, Samara, Togliatti), three Ukrainian universities, and two HEIs from Azerbaijan. This recent project was aimed at development, accumulation and caretaking of human capital 
through life-long learning promotion and social inclusion of elderly people into the system of informal and continuing education, and led to the increased number of elderly people included into the educational systems of the three countries. The universities established the Third Age Education Centres, where they now promote equality of schooling and advancement of the intergenerational exchange between seniors and younger people (http://www.tuzvo.sk/ tempus-2014-2016/en/).

\section{8) The life/ leisure model.}

\section{LLL dialogues}

One of the lasting recent LLL initiatives in Russia is the international conference «Lifelong Learning: Continuous Education for Sustainable Development», held in Pushkin Leningrad State University (base institution), together with UNESCO, Inter-Parliamentary Assembly of Eurasian Economic Community, UNESCO Institute for Lifelong Learning, Institute of Theory And History of Pedagogics of Russian Academy of Education, Institute of Regional Economics of Russian Academy of Sciences http:/lifelong-education.ru/en/ The forum started thirteen years ago and "reflects growing commonality of international interests in the field of continuous education. At the same time the globalization process in lifelong learning is not opposed to the national concepts and historical traditions in education defined and developed in a number of countries of both hemispheres of Earth" (Lifelong Learning: Continuous Education for Sustainable Development, 2015: 2)

One more indicator of LLL development in Russia is participating in international professional associations, organizations and networks. A good example is EUCEN European University Continuing Education Network (http://www.eucen.eu), supporting member institutions to develop high quality university Lifelong Learning and sharing continuing Higher Education expertise with stakeholders. By 2015, four Russian Universities became the EUCEN members: Kursk Institute of Management, National Research Tomsk State University, Peoples' Friendship University of Russia, and Russian State University of Tourism and Service.

\section{Conclusion}

Taken together, the article gives some examples of recent lifelong practices and models intended to offer insights into educational LLL field in Russia.

There is still much that needs to be practically done and discussed, but in facing current and future challenges, given illustrations may contribute to the awareness of practical agenda upon which universities, departments, educational institutions of all kinds, agencies, stakeholders and learners themselves can work together to frame proper lifelong educational movements for population.

\section{References}

Evans, K. Policy Challenges in Lifelong Learning, in Second International Handbook of Lifelong Learning, ed. by D.N. Aspin, J. Chapman, K.Evans, R. Bagnall. London, New York, Springer , 2012, Ix - Ixv.

Lifelong Learning: Continuous Education for Sustainable Development. Proceedings of the $13^{\text {th }}$ International Conference, ed. by N.A. Lobanov, V.N. Skvortsov. St. Petersburg, 2015.

Lifelong Learning: Patterns of Policy in Thirteen European Countries. A Review of Lifelong Learning Policy \& Practices in Austria, Bulgaria, the Czech Republic, England, Estonia, Flanders, 
Hungary, Ireland, Lithuania, Norway, Russia, Scotland, Slovenia. Lifelong Learning 2010, Six Framework Programme. Report of Sub-project 1, 2007.

Second International Handbook of Lifelong Learning. ed. by D.N. Aspin, J. Chapman, K.Evans, R. Bagnall. London, New York, Springer, 2012.

Zajda, J. Current Trends in Lifelong Learning in the Russian Federation: Current Developments, in Second International Handbook of Lifelong Learning, ed. by D.N. Aspin, J. Chapman, K.Evans, R. Bagnall. London, New York, Springer , 2012, 441-454.

UNICO TEMPUS project (2015), Available at: http://tempus-unico.eu/index.php/en/events/ lifelong-learning-training-london-october-2014

VALERU TEMPUS project (2015), Available at: http://valeru.net

ALLMEET TEMPUS project (2015), Available at: http://www.ec-vpl.eu/allmeet/

ECOSTREAM TEMPUS project (2015), Available at: http://ecostream.lamp-lab.ru

THIRD AGE EDUCATION TEMPUS project (2015), Available at: http://www.tuzvo.sk/ tempus-2014-2016/en/

EUCEN network (2015), Available at: http://www.eucen.eu

\title{
Обзор некоторых моделей
}

\section{и практического опыта реализации парадигмы «образование в течение жизни» в России}

\author{
Н. Керш ${ }^{\text {a }}$ В.А. Кононова ${ }^{\tilde{\sigma}}$ В.В. Обидина ${ }^{\boldsymbol{\sigma}}$

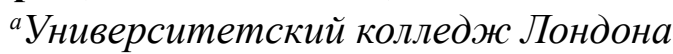 \\ Великобритания, WC1H 0AL, Лондон, Бэдфорд Уэй, 20 \\ ${ }^{\sigma}$ Сибирский федеральный университет \\ Россия, 660041, Красноярск, пр. Свободный, 79
}

\begin{abstract}
В статье рассматриваются некоторые современные российские практики имплементации парадигмы «образование в течение жизни». Авторы приводят классификачию образовательных моделей Джозефа Зайды (Австралия), иллюстрируя ее примерами современных образовательных проектов ТЕМПУС, реализуемых в последние годы в сфере высшего образования РФ.

Ключевые слова: образование в течение жизни, образовательные проекты ТЕМПУС, образовательные модели, функиионалистская модель, образовательная политика.

Статья написана при финансовой поддержке гранта программы ТЕМПУС IV Европейского Союза (проект «Создание сети университетских языковых иентров для профессионального и личностного развития человека в рамках парадигмы «образование в течение всей жизни», № 544283-TEMPUS-1-2013-1-ES-TEMPUS-JPHES).
\end{abstract}

Научная специальность: 13.00.00 - педагогические науки, 10.00.00 - филологические науки. 